\title{
CHINESE NARRATIVE SONG: STRUCTURE, LANGUAGE AND HISTORICAL DYNAMICS
}

\author{
Olga Leontovich, Natalya Simonenko \\ Volgograd State Socio-Pedagogical University \\ 27 Lenin Prospect, Volgograd, 400066, Russia
}

\begin{abstract}
The purpose of this paper is to examine the cultural and linguistic features of Chinese narrative songs of the $20^{\text {th }}$ - early $21^{\text {st }}$ centuries. They are explored through the theoretical frameworks and research instruments of narratology, cultural anthropology and linguistics (M. Bakhtin, R. Barthes, G. Genette, V. Propp, T. Todorov, etc.). The paper highlights the most important changes of narrative songs determined by historical events in China during the period under investigation: a) dynamics of themes, plots and attitudes towards related events - from ideological praise of the Communist party and Chairman Mao - to a more personalized narration about people's life and love in a globalized world; b) evolution of characters from selfless fighters for communism with clearly defined social identity — to generalized lyrical personalities motivated by love, suffering, kinship and loyalty to their country; c) growth of genre variability due to the relaxation of ideological pressure and the influence of Western musical culture; d) return to the values of ancient Chinese culture and restoration of traditional national identity, implemented in background knowledge, binary oppositions and intertextual connections; e) new forms of linguistic expression.The findings indicate that the algorithm of text analysis developed in the course of the research may be used to investigate other types of Chinese narratives, as well as narratives from other cultures.
\end{abstract}

Keywords: Chinese, narrative, song, character, culture, linguistic expression

\section{GOALS AND INSIGHTS}

The purpose of this paper is to examine the cultural and linguistic features of Chinese narrative songs of the $20^{\text {th }}$ - early $21^{\text {st }}$ centuries. They are explored through the theoretical frameworks and research instruments of narratology, cultural anthropology and linguistics. This interdisciplinary basis can be elucidated through a detailed analysis of textual characteristics of songs, their non-verbal features, as well as the cultural and historical context of their emergence and performance.

We are trying to prove the following hypothesis: Chinese narrative songs of the period under research possess both universal and culture-specific features, which are reflected in their themes, genres, character traits, plot, intertextual connections, temporal and spatial contexts, etc.

In the paper, we intend to: 1) investigate the approaches towards the study of narratives in the world in general and China in particular; 2) give a definition of a narrative song as the focal point of the research; 3) describe the methodology we use to analyse Chinese narrative songs; 4) classify and characterize the constituent features of Chinese narrative songs (narrator, characters, themes, genres, temporal and spatial dimensions, events, plots, background knowledge, binary oppositions and intertextual connections), paying special attention to the forms of their linguistic expression; 5) trace the dynamics 
of Chinese narrative songs in the $20^{\text {th }}$ - early $21^{\text {st }}$ centuries and describe the reasons for the observed changes.

The study is based on the analysis of: 1) 73 narrative songs of the $20^{\text {th }}$ - early $21^{\text {st }}$ centuries, 33 of which belong to the revolutionary period from 1924 to 1977 (Beijing revolution of 1924, Democratic revolution of 1925-1927, Civil War of 1927-1950, rule of Mao Tse-Tung in 1949 - 1977, Cultural Revolution of 1966-1976), and 40 to the period from 1978 to the present (Deng Xiao-Ping's reforms and China's Turn Westward); 2) musical video clips (total running time 305 minutes); 3) audio recordings of songs (total running time 255 minutes). The popularity of the songs was determined on the basis of Chinese official hit parades, materials of Chinese news and musical sites, as well as a number of Internet forums devoted to music.

The leading research method is narrative analysis, which seeks to investigate the structure and content of stories as textual units and aims to reveal outer and inner changes as represented by the narrator (Genette 1988; Leontovich 2011; Riessman 2004;). A text is seen as a narrative if it includes: a narrator; a reader or listener; characters; sequence of events; causal relations between them; finality of the plot; and the speaker's / writer's attitude towards the narration (Jahn 2005; Leontovich 2011).

Other research methods we employ are stylistic and interpretative analyses seeking to reveal the cultural specifics of Chinese narrative songs and their historical dynamics. The quantitative data is summed up in tables demonstrating the prevailing song characteristics and tendencies in their development.

\section{RATIONALE FOR THE PRESENT STUDY}

Previous research has not given significant attention to narrative songs in general and Chinese narrative songs in particular. We believe that it is important to work out an algorithm of narrative analysis, which would take into account their linguistic and cultural peculiarities. The study of narrative songs might be an effective way to gain a better understanding of Chinese mentality and values.

\section{THEORETICAL BACKGROUND}

The theoretical assumptions underlying the research are anchored in both classic approaches to the study of narratives and more contemporary theories.

Though traditionally it is believed that narratology originated in the $1960-1980$ s, its ideas can be traced back to the antiquity, when story-telling was regarded as a specific type of text and speech construction. The first attempts to distinguish between narrative and non-narrative texts can be found in Aristotle's Poetics (c. 335 BC) and Plato's Republic $(360 \mathrm{BC})$ where narration is subdivided into diegesis (simple narration) и mimesis (imitation), i.e. into independent narration and a story told by one of the acting characters (Genette 1988; Jahn 2005).

Narratology proper stemmed from structural linguistics represented by the works of F. de Saussure (1916), R. Jakobson (1928), V. Propp (1928), T. Todorov (1969), A.J. Greimas (1979), M. Bakhtin (1986), G. Genette (1988), etc. The term narratology 
in its today's meaning was coined by the famous French philosopher, historian and literary critic T. Todorov (1969). If originally narrative was predominantly defined as literary prose, it is nowadays interpreted broadly as any type of communication which presents a sequence of events caused and experienced by characters (Jahn 2005), which can exist in different genres and forms: as myth, legend, novel and other types of fiction, oral narration, drama, mime, painting, film, comics, etc. (Levi-Strauss 1972; Schmid 1973; Barthes 1977; Ryan; de Oliveira, Lisboa, 2017).

For our purposes it is most critical to reflect on the trends in the development of narratology in China. In the late 20th - early 21 st centuries Chinese narrative texts were mostly analysed on the basis of translated Western works. Since that time Chinese scholars have developed their own original narratological approaches presented in Lu Xun's History of Chinese short story (鲁迅 1981), Chen Ping-yuan's Transformation of the narrative model of Chinese novel (陈本原 1988), Luo Gang's Introduction into narratology (罗钢 1994), Yang Y's Chinese narratology (杨义, 1997), Shen Dan's Narratology and the study of fiction (申单 1998), Cao Wen-xuan's Doors to the narrative (曹文轩, 2003), etc. However, musical and song narratives have not yet been thoroughly investigated either by Western or Chinese scholars.

One of the key notions of our study is "narrative" defined as a structured text based on a story, which consists of a consecutive, logically constructed set of events. This kind of text always includes an emotional constituent and has a potential for multiple interpretations. The core of the narrative is an event understood as a character's transition across topographic, pragmatic, ethical, psychological or cognitive semantic borders, which possesses factuality and efficacy. A "narrative song" is written in verse, intended for vocal performance and often accompanied by music.

The Chinese narratological theory includes such notions as 叙述学 and 叙事学 corresponding to narratology, 叙述体 — narrativity, 叙述人称—narrator, 叙述时间 narrative time, 叙述空间 — narrative space. The Chinese equivalent we keep in mind for a narrative song is 叙事歌曲.

Chinese narrative songs originated during the Song dynasty from song-tales an important source of information about the history of China, its literary masterpieces, mythology and people's lives. During the 1924-1978 revolutionary period Chinese narrative songs changed their traditional function and became a vehicle of communist ideology. The period of Deng Xiao-Ping's reforms drew the Chinese and Western narratives closer together. At present narrative songs combine modern ethnocultural flavour of Chinese society and Western musical trends.

\section{CHINESE NARRATIVE SONG AS A SPECIFIC TEXT FORM}

The structural and conceptual constituents of Chinese narrative song are closely connected with the development of Chinese language and culture, people's worldview and mentality.

A narrator is a figure created by the author, the "voice" of narrative discourse communicating with the listener, reader or spectator. G. Genette (1988) distinguishes between 
homodiegetic narrators who are participants of their own stories and non-participating heterodiegetic narrators.

In 1924-1977 songs furthered certain tenets of the ideology they expressed and strengthened people's commitment to the Communist party. Heterodiegetic narrators sang praise to the joys and successes of the Chinese government, army and people, e.g. in the song 《王大妈要和本》 (“Aunt Wang is Striving for Peace”), which narrates about a common Chinese woman who is trying to do her best for the benefit of her country - a personification of Chinese people in the 1950s:
王大妈要和平,
你看她东奔西跑要呀
Aunt Wang is striving for peace,
那个要呀和平。
她每天动员妇女们
Can you see how she is running about,
Doing her best for the sake of peace.
来呀来签名,
Every day she asks young women
宣传的脑筋开了空,
道理懂得清。
你看她东奔西跑
要呀那个要呀和平。
$<\ldots>$
她到处宣传不消停。
逢人她就讲：
to come and subscribe,
Enlightening and encouraging them,
Explaining to them what is going on.
Can you see how she is striving for peace.
“大家来签名,
$<\ldots>$
大家要齐心,
我们要反对
挑动战争的破坏和平的
美国强盗杜鲁门”。
$<\ldots>$
She is constantly campaigning.
Telling everybody:
«Let us all subscribe,
$<\ldots>$
Let us unite our hearts,
We must oppose those
Who are fuelling the war,
We must oppose the American warmonger Truman.

The end of the $20^{\text {th }}$ century was marked by the emergence of numerous songs with homodiegetic narrators $(72,6 \%)$ - participants of events, empathizing with the feeling of characters described in the song. spectives:

We analyse characters and their place in narrative songs from the following per-

1) explicit / implicit characteristic;

2) autocharacterictic / alterocharacteristic;

3) identity;

4) authorship and completeness of the description;

5) constancy / dynamics;

6) role in the narrative.

By means of this approach we provide an integrated coverage of social diversity of characters, their culture-specific features and manner of interaction in the context of the narrative. The analysis of physiological, psychological and social identity of characters and the ways of their verbalization has helped us to identify what is valued and what is condemned in Chinese society. 
The idea of beauty is expressed through its Chinese perception and verbalized with the help of various linguistic figures and traditional symbols. The central character of the song 《月光下的凤尾竹》 (“Bamboo in the Moonlight") playing the Chinese folk instrument hulusheng (葫芦笙) uses the idiom 光彩夺目 (“radiance blinds") to describe the young woman he loves. He compares her to ye-ming-zhu, a pearl shining in the dark (夜明珠), and a golden pheasant (金孔雀), the symbol of female beauty, originating from the ethnic cultures of the Yunnan province:

竹楼里的好姑娘。
光彩夺目像夜明珠听啊。
多少深情的葫芦笙
对你倾诉着心中的爱慕。
哎金孔雀般的好姑娘,
为什么不打开䒝你的窗户?

A beautiful young woman lives in a bamboo house. I can't take my eyes off her, She is like a pearl shining in the dark. The heartfelt hulusheng melody Expresses my love.

Oh, you are as beautiful as a golden pheasant, Why won't you open your window?

Positive psychological features, which are explicitly or implicitly reflected in narrative songs, include such universal qualities as intelligence, diligence, loyalty to one's country, reliability, love for family and friends, responsibility for children, wish to help those who need assistance and ability to be grateful. Culture-specific features are: collectivism, prevalence of public good over personal interests, respect for the elders, great value of Chinese history, pride in the Chinese language and culture. The qualities that are universally condemned include: cruelty, injustice, rudeness, immorality, unscrupulousness, cowardice, use of foul language and love of gossip. Culture-specific negative features verbalized in the songs are the betrayal of the Communist party, loss of face, loneliness and poverty.

Social characteristics directly or indirectly reflected in the songs are: gender, age, geographical and professional identity, financial standing and political affiliation. The prevalence of masculine characters $(61,4 \%$ of all the songs where the character's gender is explicitly expressed) may partially stem from a higher position men held in Chinese society in the past; however, nowadays women often play leadership roles, which inevitably influences song narratives. Age identity is reflected in the young people's future-oriented vision and the reverence for the old people firmly established in Chinese cultural tradition.

The description of geographical identity in the song lyrics generally points to the pride in the unity of Chinese nation and loyalty to its culture. However, we have come across examples where it becomes a tool for criticizing people who do not live up to the social expectations. The song 《东北人都是活雷锋》 (“All the People of the NorthEast are live Lei Fengs") created at the beginning of Deng Xiao-Ping's reforms is filled with sarcasm. Its character old Zhang is shown as a typical representative of the NorthEast, with his unchanging habits and preferences, emphasised by the use of language reflecting the culture and everyday life of the region:

俺们那嘎都是东北人。 俺们那嘎盛产高丽参。 俺们那嘎猪肉炖粉条。 俺们都是活雷锋。
We all say that we are people of the North-East.

We all say that we have a lot of Korean ginseng.

We all say that we are in the habit of stewing pork with noodles

And that we are all live Lei Fengs. 
The stylistic device of antonomasia “活雷锋” (“live Lei Feng”) invokes the image of a follower of the Chinese Communist party who existed in reality and whom Chairman Mao named a paragon of selflessness and readiness to come to the aid of his compatriots. Since Lei Feng came from the North-East of China, his fellow countrymen claim that they are also selfless and always ready to help others. However, in the song old Zhang is hit by a car, and the driver escapes without coming to his rescue. The narrator sarcastically remarks he must have come from some other region because people from the North-East do not behave in such a fashion.

The songs of the revolutionary period $(60,6 \%)$ indicate the characters' place in society and struggle for communist ideals. During the period of reforms (since 1978) those indications become less common (10,5\%); more attention is given to their material possessions: financial well-being is seen as positive, and poverty - as negative.

Political affiliation is easily traced in the songs of the revolutionary period praising Communist ideals. E. g. the song 《小河水清幽幽》(“The Water in the Creek is Quiet and Clear") narrates about the work and feats of the Chinese People's Liberation Army:

你们是咱们的亲骨肉。
你们是咱们的知心人。
党的恩情说不尽。
见了你们总觉得格外亲。

The derogatory terms used for the enemies of communist ideology include: 旧社会 (“old society”), 反动分子 (“reactionaries”), 美帝 (“American imperialism”), 苏修 (“Soviet revisionism”), 害人虫 (“saboteurs”), 狗汉奸 (“dogs — traitors”), 狼群 (“wolfpack”), 豹狼 (“jackals and wolves” meaning “cruel and greedy people”), 美国鬼 (“American devil"), 纸老虎 (“paper tiger" meaning "bugaboo"), etc. During the period of reforms (since 1978) the references to the characters' political affiliation have practically disappeared, and the songs are more often devoted to universal human values.

The themes of Chinese narrative songs of the $20^{\text {th }}$ - early $21^{\text {st }}$ centuries are summed up in Table 1, which shows the number of songs devoted to each theme and their percentage.

\begin{tabular}{|l|c|c|c|}
\multicolumn{1}{|c|}{ Themes of narrative songs } & $\begin{array}{c}\text { 1924-1977, } \\
\text { number }(\%)\end{array}$ & $\begin{array}{c}1978 \text { г. }- \\
\text { present, } \\
\text { number }(\%)\end{array}$ & $\begin{array}{c}\text { Total } \\
\text { number }(\%)\end{array}$ \\
\hline Love & $6(18,2)$ & $26(65)$ & $32(43,8)$ \\
\hline Struggle with enemies & $7(21,3)$ & $3(7,5)$ & $10(13,8)$ \\
\hline Success of the party and the people & $11(33,4)$ & 0 & $11(15,1)$ \\
\hline Happiness in personal life & $3(9)$ & $4(10)$ & $7(9,6)$ \\
\hline War songs and songs about the army & $4(12,1)$ & $1(2,5)$ & $5(6,8)$ \\
\hline Chinese habits and customs & $1(3)$ & $2(5)$ & $3(4,1)$ \\
\hline Love for parents & $1(3)$ & $1(2,5)$ & $2(2,7)$ \\
\hline Friendship & 0 & $2(5)$ & $2(2,7)$ \\
\hline Family & 0 & $1(2,5)$ & $1(1,4)$ \\
\hline Total number of songs & 33 & 40 & 73 \\
\hline
\end{tabular}


The prevalent theme during the revolutionary period of $1924-1977$ is the success of the Communist party and Chinese people. Song lyrics are filled with grandiloquent epithets singing praise to communist ideology.

Another common theme of this period is the struggle with enemies - foreign invaders, as well as inner foes adherent to old principles and ideas who do not believe in the revolution. One of the examples is the quotation from the song 《唱支山歌给党听》 ("Mountain Song is Sung for the Party"). The significance here lies in the phrasing of the lyrics:

$\begin{array}{ll}\text { 共产党号召我闹革命, } & \text { The Communist party claims freedom for the revolution - } \\ \text { 夺过鞭子, } & \text { To grab a whip, } \\ \text { 夺过鞭子揍敌人！ } & \text { Grab a whip and beat the enemy! }\end{array}$

Beginning with the reform period (since 1978) the majority of the songs $(65 \%)$ have been devoted to romantic love between man and woman. Political songs of that period praise the Communist party but do not call for revolutionary action. The decrease of the number of songs about the struggle with enemies reflects changes in the political course of the Communist party at the end of the $20^{\text {th }}$ century, as well as the growth of interest for foreign cultures during the epoch of globalization.

Genre differentiation. Prevalent in the revolutionary period were the songs of the epic genre, whereas the period of reforms gives preference to the lyrical genre. The late $20^{\text {th }}$ century was marked by the emergence of ironic and satirical songs, as well as those intended for dancing. The growth of the genre variability can be explained by the relaxation of ideological pressure, as well as the influence of Western song culture.

Temporal dimension. The analysis of the correlation between narrative and discursive time in Chinese narrative songs has demonstrated common use of simultaneous accelerated narration revealing characters' emotions, in many cases describing a lengthy time period and allowing the listener to feel involved in the events. The peculiarity of a song as a compact-size narrative accounts for the prevalence of chronological narration with frequent repetitions, which simplify its audial perception and its impact on the listener.

The narrator of the song 《光阴的故事》 (“Bright Story”) projects the Chinese perception of time as a cyclic process on his relationship with the woman he loves:

春天的花开秋天的风以
及冬天的落阳。
忧郁的青春年少的我會
经无知的这么想。
风车在四季轮回的歌里
在天天地流转。
风花雪月的四季里我在
年年的成长。
流水它带走光阴的故事
改变了一个人。
就在那多愁善感而初次
等待的青春。

"Flowers bloom in spring, the wind blows in autumn, the sun disappears in winter" -

This is what I thought at the times of sadness when I was ignorant and young.

But the windmill in the kaleidoscope of seasons is still spinning in the vastness of nature.

Year after year I lived through the winds and flowers, the snows and the moons of the four seasons.

The bright story as a water stream has changed me.

And after so much sadness, so many thoughts and feelings the first long-awaited spring has come. 
The feelings of the characters are changing alongside with the change of seasons: they meet and part, then for a long time suffer because of the separation. At the end of the song, after many years apart, they manage to return to their first spring, i.e. reunite and live together.

Spatial dimension. During the revolutionary period it was common to glorify particular provinces, cities, villages and natural landscapes. This was achieved through the use of numerous toponyms, such as names of cities (Beijing, Jiangnan, Jiangbei), villages (Turfan), islands (Hainan, Xianggang), mountains (Tianshan, Wushishan, Himalayas), rivers (Yangtze, Huang he, Brahmaputra), etc. It was done to upswing people's patriotic sentiment and unite them. In the late $20^{\text {th }}$ century the role of songs in supporting the Communist party's role decreased; the accurate indication of place names gave way to personified events and the possibility of extrapolating action to different loci.

Plot and events. The most frequently used plots of the revolutionary period were about: a) people who had suffered under the previous regime but whose lives improved when the Communist party came to power; they work for its benefit, praising Chairman Mao, making progress and being useful for society; b) people who are party members fighting the opposition - not only foreign enemies (imperialism, revisionism, etc.), but also "the harmful elements" within China who do not agree with the party's politics.

The period of reforms brought about change of the popular plots: a) the characters (man and woman) are first together, and nothing in their relationship presages any disaster; however, later in life they face difficulties but preserve their feelings for each other, overcome hardships and are reunited; b) the male character makes efforts to win the heart of his beloved and she finally reciprocates his feelings; в) the character works hard, follows moral principles, has to overcome many obstacles, but nevertheless, remains a dignified, noble, understanding person with a strong spirit. As a rule, the final lines of a song sum up the idea of the whole narrative or express the narrator's attitude towards the story.

Background knowledge, which is essential for an adequate understanding of Chinese narrative songs, is implicitly present in the text and is connected with cultural and historical events, socially significant facts and Chinese life during ancient or modern times. E.g. the narrator of the song 《库尔班大叔你去哪》 (“Uncle Ku Er-ban, Where are you Going?") describes himself in the following way:

$\begin{array}{ll}\text { 我赶着马儿离开了。 } & \text { I jump on the horse and depart. } \\ \text { 腰上还带着水葫芦, } & \text { I stick a hulu under my belt, } \\ \text { 手里还拿着冬不拉, } & \text { I am holding a dong-bu-la in my hand, } \\ \text { 崭新的袷袢身上穿。 } & \text { And I am wearing my new qiapan. }\end{array}$

It is worthwhile explaining that the narrator is going to celebrate the Day of the Chinese People's Liberation Army. He dresses up, and his new qiapan (front-buttoning robe) symbolizes his aspirations and hopes. The fact that he is holding a dong-bu-la (dombra, Kazakh folk instrument) in his hands tells us that he lives in Western China, because Kazakhs live in Xinjiang Uyghur Autonomous Region. The hulu (shui-hu-lu) is an artefact - a water vessel which has been used in China since ancient times. It is 
a symbol of wealth because water used to be of great value. The hulu was also used to make the Chinese folk wind instrument hu-lu-si (葫芦丝). However, the narrator is speaking about a water vessel, which is indicated by the character 水 (water).

It is also interesting to investigate the ethnocultural characteristics of the song 《开心过年》(“We are Happily Seeing in the New Year"), which invites listeners to celebrate the Chinese Spring Festival. The refrain describes the celebration traditions:

$\begin{array}{ll}\text { 给你一个红包, } & \text { I'll give you a hong-bao, } \\ \text { 说好话, } & \text { Say good words } \\ \text { 开心笑哈哈, } & \text { And laugh happily. } \\ \text { 换上新衣、戴新帽、 } & \text { I'll put on new clothes, a hat, } \\ \text { 新鞋和新袜。 } & \text { Boots and socks. } \\ \text { 时间滴答答 } & \text { Time is running, } \\ \text { 带着梦想慢慢发芽。 } & \text { And all dreams are coming true. }\end{array}$

A hong-bao is a red decorated envelope for money presented to family members, especially children, as a gift, or at work as a bonus on the occasion of the New Year.

The semiotics of Chinese songs is represented by different kinds of symbols, which help the listener to grasp the relationship between the narrator's subjective experience and its communicability. E.g. the title of the song 《东风破》 ("The Gusts of Eastern Wind") and its lyrics are associated with the Eastern wind as a symbol of inconstancy. The main character has seen off the woman he loves on a long journey, she promised to come back but never did. He is singing about the gusts of Eastern wind, i.e. the inconstancy of feelings of his beloved. The song performed in the modern manner is deeply rooted in history and has preserved the Chinese melody from the times of the Tang and Song dynasties. The musical instruments $e r-h u$ и qin-pi-pa create sounds imitating the wind.

“The Song of the Four Seasons" 《四季歌》narrates about the life of a young woman who participates in the construction of "the Great Wall of China." In this context the nomination is used figuratively to denote an ideological, communist "wall" under Chairman Mao's leadership. The narrator allegorically correlates the woman's life changes with the sequence of seasons: spring personifies her meeting with the man she loves, summer - her life in a new place with her husband, autumn - longing for their relatives, winter - her husband's tragic death:
冬季到来雪茫茫,
寒衣做好送情郎。
And winter came covering everything with snow.
血肉筑出长城长,
She sews winter clothes and gives them to her beloved.
奴愿做当年小孟姜。
He was building the Great Wall of his own flesh,
And she desires to become Meng Jiang this same year.

The last two lines contain historical allusions relevant for each Chinese person. The line "He was building the Great Wall of his own flesh" is the rephrasing of the Chinese anthem “The March of Volunteers”: “把我们的血肉筑成我们新的长城” (“We are building the Great Wall of our own flesh"), which denotes loyalty to the Communist party and readiness to sacrifice oneself for its ideals. However, the female charac- 
ter “desires to become Meng Jiang” (“奴愿做当年小孟姜”) whose husband died during the construction of the real Great Wall of China. Just like her, the female character wants to ruin this "wall" metaphorically constructed of real people's flesh, to erode it with her own tears. In this way the simple description of a young family's life becomes a reference to a long period of Chinese history. The song is a vivid example of the extension and compression of time with the help of succinct metaphors, allegories, similes and allusions to important cultural and historical events.

Narrative songs are typically built around binary oppositions, which correlate with basic perceptions, key values and historical changes in Chinese society. They include universal oppositions ("good — bad", "big — small", "young — old", "cold — warm", "at home — abroad", "courage — cowardice", "love — "infidelity," etc.) and Chinese culture-specific oppositions ("without the party — with the party", "stability — changeability", "fast - slow flow of time," etc.).

Intertextual connections reflected in narrative songs (allusions to famous literary works, old manuscripts, inscriptions on the walls, works by famous Chinese thinkers and philosophers) provide for the historical continuity, preservation of Chinese literary and cultural traditions, and handing them down from one generation to another.

The song 《光阴的故事》 (“The Bright Story”) discussed above contains the line “风花雪月的四季里我在年年的成长”. The first four characters “风花雪月” are translated as "wind, flowers, snow, moon." This chengyu (idiomatic expression) can be traced back to the Yunnan coupled inscriptions on calligraphic panels:
上关花，下关风， Flowers are blooming in Shangguan, the wind is blowing in Xiaguan, 下关风吹上关花； 苍山雪, 洱海月, 洱海月照苍山雪。 The wind from Xiaguan is blowing on the flowers in Shangguan; There is snow on the Cang Montain, and the moon is shining above lake Erhai, The Moon of lake Erhai lights up the snow on the Cang Montain.

"Wind, flowers, snow and moon" represent the most famous landscapes of the autonomous district Dali in the Yunnan province. Shangguan is a vast steppe and Xiaguan is a mountainous region; the wind blowing from there refreshes the flowers in Shangguan. The top of the majestic mountain Cang is covered with white snow. At night lake Erhai acquires the colour of the sky, and the moon reflected in it is called "the moon of lake Erhai". Nowadays this phrase expresses the beauty of the four seasons and is a symbol of romantic relations. Therefore, the line “风花雪月的四季里我在年 年的成长” should be translated as "Year after year I lived through spring, summer, autumn and winter [without you]".

Some figures of speech originated from ancient works by Chinese thinkers and philosophers. The song 《开心过年》(“We are Happily Seeing in the New Year" quoted above refers to the set of four tastes (bitter, spicy, sour and sweet), which is a metaphorical representation of joyful and sad moments of life: “生活里有苦辣酸甜” ("Life holds both troubles and joys"). The expression can be traced back to Li Luyuan's $18^{\text {th }}$ century manuscript “Light at the Crossroads" (清李绿园《歧路灯》): “If you desire to earn money only for the sake of clothes and food, you won't be able to nar- 
rate about the twists and turns of life” (“无非为衣食奔走；图挣几文钱；那酸甜苦 辣也就讲说不起”).

Historical dynamics of Chinese narrative songs influences their themes, narrators, characters and other narrative constituents. During the revolutionary period the themes which prevailed in narrative songs were the feats of the Communist party and the Chinese People's Liberation Army. The text of such songs is characterized by high-flown, enthusiastic rhetoric, use of expressive lexemes, flamboyant epithets, metaphors, stylistic repetitions and other figures of speech:

主席的话儿记心上,
哪怕敌人逞凶狂,
咱们埋下了天罗地网哎,
要把那些强盗豹狼全都埋葬,
全都埋葬, 把他们全埋葬!

Chairman Mao's words sank deep into our souls, And even if the enemies are cruel and aggressive, We have prepared traps from which they won't be able to escape, We have to bury all those greedy and cruel people, jackals and outlaws, We have to bury, bury them all!

The beginning of Deng Xiao-Ping's period of reforms was marked by the emergence of a growing number of narrative songs with the motives of romantic love. At first the couples tended to find their happiness in the loyalty to communist ideals, as in the song 《我们的生活充满阳光》 (“Our Life is Filled with Sunlight”):

幸福的花儿心中开放。
爱情的歌儿随风飘荡。
我们的心儿飞向远方
憧憬那美好的革命理想。
The flowers of happiness are blooming in my heart,

The song of love is brought by the wind.

And our hearts are flying far away

In the dreams about goodwill and revolutionary ideals.

By the end of the $20^{\text {th }}$ century romantic songs no longer included references to politics or economics, they only recounted of the characters' feelings, as in the song 《千里之外》 (A Thousand Li Away”):
你从雨中来, 诗化了悲哀, 我淋湿现在。 芙蓉水面采, 船行影犹在, 你却不回来。 被岁月覆盖 你说的花开 过去成空白。

You are made of rain And turn my sufferings into poetry. And while I am getting wet under the rain, The beautiful lotus is absorbing the vital moisture. The shadow of the boat passing by has not yet disappeared, But you will never come back. After so many years the flower About which you used to say so much Turned out to be a barren flower.

The use of extended metaphors ("the beautiful lotus," "flower," "barren flower") for the description of the characters' state and behaviour is deeply rooted in the Chinese song-tale tradition which we mentioned above. The period of reforms brought back old Chinese symbols and images of nature. 
The plots of the songs also evolved over time. In China the text of a song with the same melody can significantly change due to the political situation. We will quote three variants of the song 《我们走在大路上》("We are Walking along a Large Road») where the music was preserved but the texts changed in accordance with the historical events:

Table 2

\begin{tabular}{|c|c|c|}
\hline Great leap forward & Cultural Revolution & Modern times \\
\hline $\begin{array}{l}\text { 我们走在大路上, } \\
\text { 意气风发斗志昂扬, } \\
\text { 毛主席领导革命队伍, }\end{array}$ & $\begin{array}{l}\text { 我们走在大路上, } \\
\text { 高举红磌向太阳, } \\
\text { 毛主席领导革命队伍, }\end{array}$ & $\begin{array}{l}\text { 我们走在大路上, } \\
\text { 意气风发斗志昂扬, } \\
\text { 共产党领导革命队伍, }\end{array}$ \\
\hline $\begin{array}{l}\text { We are walking along a large road, } \\
\text { Inspired and full of the battle } \\
\text { spirit, } \\
\text { Chairman Mao is at the head of } \\
\text { the revolutionary unit }\langle\ldots\rangle \text {. }\end{array}$ & $\begin{array}{l}\text { We are walking along a large road, } \\
\text { The red banner high above faces } \\
\text { the sun, } \\
\text { Chairman Mao is at the head of } \\
\text { the revolutionary unit }\langle\ldots . .>\text {. }\end{array}$ & $\begin{array}{l}\text { We are walking along a large road, } \\
\text { Inspired and full of the battle } \\
\text { spirit, } \\
\text { The Communist party is at the } \\
\text { head of the revolutionary unit }\langle\ldots\rangle \text {. }\end{array}$ \\
\hline
\end{tabular}

It can be seen from the quoted examples that during the periods of the Great Leap Forward and the Cultural Revolution priority was given to Chairman Mao; people followed him as the personification of revolutionary spirit. In the modern version after Mao's death (1976), the revolutionary unit is headed by the generalized Communist party.

The song also reflects different attitudes towards other countries and their perception as enemies or friends:

Table 3

\begin{tabular}{|c|c|c|}
\hline Great leap forward & Cultural Revolution & Modern times \\
\hline $\begin{array}{l}\text { 我们的朋友遍天下, } \\
\text { 我们的歌声传四方, } \\
\text { 革命风暴席卷全球, } \\
\text { 牛鬼蛇神一片惊慌。 }\end{array}$ & $\begin{array}{l}\text { 我们的朋友遍天下, } \\
\text { 我们的歌声传四方, } \\
\text { 革命风暴席卷全球, } \\
\text { 美帝苏修一定灭亡。 }\end{array}$ & $\begin{array}{l}\text { 我们的道路酒满阳光, } \\
\text { 我们的歌声传四方, } \\
\text { 我们的朋友遍及全球, } \\
\text { 五洲架起友谊桥梁。 }\end{array}$ \\
\hline $\begin{array}{l}\text { Our friends are all over the } \\
\text { Celestial Empire, } \\
\text { And our song can be heard at } \\
\text { all the four sides of the world, } \\
\text { Our revolutionary storm is } \\
\text { known all over the globe, } \\
\text { All the rascals are in panic, } \\
\text { all of them. }\end{array}$ & $\begin{array}{l}\text { Our friends are all over the Celestial } \\
\text { Empire, } \\
\text { And our song can be heard at all the } \\
\text { four sides of the world, } \\
\text { Our revolutionary storm is known all } \\
\text { over the globe, } \\
\text { And American imperialism and Soviet } \\
\text { revisionism will surely be annihilated. }\end{array}$ & $\begin{array}{l}\text { Our road is filled with sunlight, } \\
\text { And our song can be heard at all } \\
\text { the four sides of the world, } \\
\text { Our friends live all over the globe, } \\
\text { Bridges of friendship lead to all the } \\
\text { five continents. }\end{array}$ \\
\hline
\end{tabular}

The combination of these three versions can be regarded as three parts of one narrative about the revolution in China where the spirit and perception of the world changes over time due to the evolution of the Communist party's politics. This plot occupies one of the leading places in Chinese narrative songs. First Chairman Mao unites and inspires people who support his ideas and fights political dissidents within the country. Later, when the Cultural Revolution gains momentum, the revolutionary army is ready to struggle against unwelcome ideologies, such as "American imperialism" and "Soviet revisionism." The period of reforms and openness transforms Chinese songs together with political rhetoric: the Chinese government builds "bridges of friendship" establishing political, economic and cultural connections all over the world. 


\section{RESULTS OF THE RESEARCH}

The research has proved the hypothesis formulated at the beginning of the paper: Chinese narrative songs of the $20^{\text {th }}$ - early $21^{\text {st }}$ centuries possess both universal and culture-specific features, which are reflected in their themes, genres, character traits, plots, intertextual connections, temporal and spatial context, etc.

Formulated below are the major results we have obtained in the course of the investigation.

1. A narrative song is defined as a structured verse based on a story, which consists of a consecutive logically constructed set of events. It includes an emotional constituent, offers the reader a multiple choice of interpretations and is intended for vocal performance, often with musical accompaniment.

2. The analysis of verbally expressed narrators' and characters' features provides an integrated coverage of social diversity, reveals the regularities in the choice of characters, their culture-specific features and sheds light on the manner of interaction in the context of narrative. Positive Chinese culture-specific features are: collectivism, prevalence of public good over personal interests, respect for the elders, great value of Chinese history, pride in the Chinese language and culture. Negative characteristics are: the betrayal of the ideas of the Communist party, loss of face, loneliness and poverty.

3. The diachronic analysis of Chinese narrative songs indicates that during the $20^{\text {th }}$ early $21^{\text {st }}$ centuries they have undergone significant changes, which include:

a) dynamics of themes, plots and attitudes towards related events - from ideological praise of the Communist party and Chairman Mao - to a more personalized narration about people's life and love in a globalized world;

b) the evolution of characters from selfless fighters for Communism with clearly defined social identity — to generalized lyrical personalities whose behaviour is determined by such factors as love, suffering, kinship, loyalty to their country, etc.;

c) the growth of genre variability of songs due to the relaxation of ideological pressure and influence of Western musical culture;

d) return to the values of ancient Chinese culture and restoration of traditional national identity, implemented in background knowledge, binary oppositions, and intertextual connections;

e) substantial change of linguistic expression: departure from the abundant use of political terminology, redundant expressivity and grandiloquence; revival of poetic forms and stylistic devices aimed at the creation of the lyrical mood of the narrative.

\section{CONCLUSION}

The aim of the paper was to explore the cultural and linguistic features of Chinese narrative songs of the $20^{\text {th }}$ - early $21^{\text {st }}$ centuries. This was achieved through the theoretical frameworks and research instruments of narratology, cultural anthropology and linguistics, with special emphasis on the works by Chinese scholars.

Chinese narrative song was viewed as a specific text form. We traced the dynamics of characters, prevalent themes, genres, plots and events due to political changes in Chinese society during the period under investigation - from ideological praise of the Com- 
munist party and Chairman Mao - to a more personalized narration about people's life and love in a globalized world. We also focused on the temporal and spatial dimension of Chinese narrative songs, as well as the role of background knowledge, binary oppositions and intertextual connections.

The findings indicate that the algorithm of text analysis developed in the course of the research may be employed for the investigation of other types of Chinese narratives, as well as the comparative study of narratives from different cultures.

(C) Olga Leontovich, Natalya Simonenko, 2017

\section{REFERENCES}

Bakhtin, M. M. (1986) Jestetika slovesnogo tvorchestva [Aesthetics of word creativity]. Moscow: Iskusstvo.

Barthes, R. (1977) Poétique du récit. Paris: Editions du Seuil.

de Oliveira M.C., Lisboa C.M. Narratives about Displacement and Stigmatization of Identities // Russian Journal of Linguistics / Ed. O. Leontovich. 2017. Vol. 2, No. 2. P. 320-334.

Genette, G. (1988) Narrative Discourse Revisited. Itaca, NY: Cornell University Press.

Greimas, A.-J., Courtés, J. (1979) Semiotics and Language: An Analytical Dictionary. Bloomington: Indiana UP.

Jahn, M. (2005) Narratology: A Guide to the Theory of Narrative. English Department, University of Cologne. http://www.uni-koeln.de/ ame02/pppn.htm. Accessed 15 December, 2016.

Jakobson, R. (1928) Proposition au Premier Congres International de Linguistes. In Actes du Ier congrès international des linguistes du 10-15 avril, 1928 (pp. 33-36).

Leontovich, O. A. (2011) Metody kommunikativnyh issledovanij [Methods of communication studies]. Moscow: Gnozis.

Levi-Strauss, C. (1972) Structuralism and Ecology. Barnard Allumnae, Spring.

Propp, V. (1928) Morfologija skazki. Leningrad: ACADEMIA.

Riessman, C. K. (2004) Narrative Analysis. In The Sage Encyclopedia of Social Science Research Methods / Eds. W. S. Levis-Beck, A. Bryman and T. F. Liao. Thousand Oaks, Calif.: Sage.

Ryan M.-L. Narration in Various Media. http://www.lhn.uni-hamburg.de/article/narration-variousmedia. Accessed 2 February, 2015.

Saussure, F. (1916) Cours de linguistique générale. Lausanne, Paris: Payot.

Schmid, W. (1973) Der Textaufbau in den Erzählungen Dostoevskijs. Beihefte zu Poetica. München: Wilhelm Fink Verlag.

Todorov, T. (1969) Grammaire du Décaméron. The Hague: Mouton.

曹文轩 (Cao Wen-xuan) (2003). 《小说门》[Doors to the narrative]. 作家出版社.

陈平原 (Chen Ping-yuan) (1988) 中国小说叙事模式的转变 [Transformation of the narrative model of Chinese short story]. 上海人民出版社.

罗钢 (Luo Gang) (1994). 叙事学导论 [Introduction into narratology]. 云南人民出版社.

鲁迅 (Lu Xun) (1981). 《中国小说史略》 [History of Chinese short story]. 人民文学出版社.

申单 (Shen Dan) (1998). 《叙述学与小说文体研究》 [Narratology and the study of a novel]. 北京大学出版社.

杨义 (Yang Yi’s) (1997). 中国叙事学 [Chinese narratology]. 北京人民出版社. 
Article history:

Received: 20 August 2017

Revised: 23 September 2017

Accepted: 10 October 2017

\title{
For citation:
}

Leontovich, O. Simonenko, N. (2017) Chinese Narrative Song: Structure, Language and Historical Dynamics. Russian Journal of Linguistics, 21 (4), 789-804. DOI: 10.22363/2312-91822017-21-4-789-804.

\section{Bio notes:}

Olga Leontovich, Ph. D., Professor and Chair, Department of Intercultural Communication and Translation, Volgograd State Socio-Pedagogical University. Research interests: communication studies, linguistics, cultural anthropology, intercultural communication. Contact information: http://vgpu.org/node/4183 e-mail: olgaleo@list.ru

Natalya Simonenko, Ph. D., Associate Professor, Department of Intercultural Communication and Translation, Volgograd State Socio-Pedagogical University. Research interests: narratology, linguistics, cultural anthropology, Chinese language. Contact information: http://vgpu.org/node/4164 e-mail: natalia-siyu@yandex.ru

\section{КИТАЙСКАЯ НАРРАТИВНАЯ ПЕСНЯ: СТРУКТУРА, ЯЗЫК, ИСТОРИЧЕСКАЯ ДИНАМИКА}

\author{
О.А. Леонтович, Н. Симоненко \\ Волгоградский государственный социально-педагогический университет \\ 400066, Волгоград, Россия, пр-т Ленина 27
}

\begin{abstract}
Цель статьи - анализ лингвокультурных особенностей китайских нарративных песен XX начала XXI вв. Исследование проводится с позиций нарратологии, культурной антропологии и лингвистики (Р. Барт, М. Бахтин, Ж. Женетт, В. Пропп, Ц. Тодоров и др.). В статье прослеживается динамика нарративной песни, обусловленная историческими событиями в Китае в исследуемый период: а) изменение тематики, сюжетов и отношения к повествованию - от идеологического восхваления коммунистической партии и вождя Мао - к личностному описанию жизни и любви человека в глобализованном мире; б) эволюция персонажей — от самоотверженных борцов за коммунистические идеалы с четко обозначенной социальной идентичностью - до обобщенных лирических героев, движимых любовью, страданиями, заботой о ближнем, верностью родине; в) рост жанрового разнообразия вследствие ослабления идеологического контроля и влияния западной музыкальной культуры; г) возврат к ценностям древнекитайской культуры и восстановление традиционной национальной идентичности, воплощенной в фоновых знаниях, бинарных оппозициях и интертекстуальных связях; д) новые формы языкового выражения. Алгоритм текстового анализа, разработанный в ходе исследования, может быть применен к другим типам китайских нарративов, а также экстраполирован на нарративы из иных лингвокультур.
\end{abstract}

Ключевые слова: китайская лингвокультура, нарратив, песня, персонаж, средства языкового выражения 


\section{История статьи:}

Дата поступления в редакцию: 20 августа 2017

Дата принятия к печати: 10 октября 2017

\section{Для цитирования:}

Leontovich, O. Simonenko, N. (2017) Chinese Narrative Song: Structure, Language and Historical Dynamics. Russian Journal of Linguistics, 21 (4), 789-804. DOI: 10.22363/2312-91822017-21-4-789-804.

\section{Сведения об авторах}

Ольга Аркадьевна Леонтович, доктор филологических наук, профессор, зав. кафедрой межкультурной коммуникации и перевода Волгоградского государственного социально-педагогического университета. Сфера научных интересов: теория коммуникации, лингвокультурология, межкультурная коммуникация. Контактная информащия: http://vgpu.org/node/4183 e-mail: olgaleo@list.ru

Наталья Юрьевна Симоненко, кандидат филологических наук, доцент кафедры межкультурной коммуникации и перевода Волгоградского государственного социально-педагогического университета. Сфера научных интересов: нарратология, лингвокультурология, китайский язык. Контактная информация: http://vgpu.org/node/4164 e-mail: natalia-siyu@yandex.ru 